http://journal.nafo.int

J. Northw. Atl. Fish. Sci., Vol. 6: 141-148

\title{
Eastward Extension of the Distribution of the Marine Cladoceran (Penilia avirostris) in the Northwest Atlantic: a Case of Ecesis?*
}

\author{
J. B. Colton, Jr. \\ National Marine Fisheries Service, Northeast Fisheries Center \\ Narragansett Laboratory, Narragansett, Rhode Island, USA, 02882
}

\begin{abstract}
Data are presented on the distribution and abundance of Penilia avirostris Dana in continental shelf waters, Cape Hatteras to Nova Scotia, during 1980 and 1981. Penilia occurred in the plankton samples during approximately 6 months of the year (June-July to December). During periods of maximum abundance, Penilia occurred throughout the Middle Atlantic Bight and in isolated patches on Georges Bank, which represents an eastward extension of its previously-reported distribution. This eastward spread corresponds to the previously-documented direction of range expansion, but it is at variance with the westerly direction of residual drift. The absence of Penilia in the Gulf of Maine and seaward of the shelf break (outside 200-m isobath) indicates that some minimum level of bottom water temperature, which is necessary to initiate the development of resting eggs $\left(\sim 10^{\circ} \mathrm{C}\right)$, may be a determinant of the observed distributional patterns.
\end{abstract}

\section{Introduction}

Three genera and seven species of marine Cladocera occur in estuarine and neritic waters of the Northwest Atlantic: Podon leuckarti G. O. Sars, P. intermedius Lilljeborg, $P$. polyphemoides Leuckart, Evadne tergestina Claus, E. nordmani Loven, E. spinifera Muller, and Penilia avirostris Dana. Penilia is of special interest because it has an extremely sporadic and discontinuous distribution and is the only truly marine taxon among the many hundred species of filter-feeding Branchiopoda. Penilia has been recorded from the shores of every continent, frequently in tremendous numbers, but from widely separated locations and often only during a single season. As with other cladocerans, the periods of abundance are always associated with a high rate of ovoviviparous parthenogenesis. The populations of Penilia are renewed each year from benthic resting eggs which are produced in the autumn by sexual reproduction. After the resting eggs develop in the spring, there are a number of generations with no males.

Zooplankton surveys of the Middle Atlantic Bight and the Gulf of Maine have been restricted, for the most part, to small geographic areas and to short periods of time, and consequently few data are available as to species abundance and distribution for extended time periods or areas. Published reports of occurrence of Penilia along the east coast of the United States are summarized in Table 1.

A striking case of the adventitious occurrence of Penilia is its sudden appearance in 1944 in the wellstudied waters at Woods Hole, Massachusetts (Lochhead, 1954). The previous northern record for this species in the Northwest Atlantic was in Block Island

TABLE 1. Reported occurrences of $P$. avirostris off the Atlantic coast of the United States north of Cape Hatteras.

\begin{tabular}{|c|c|c|}
\hline Location & Month and year & Reference \\
\hline Beaufort, N. C. & June, 1898 & Sudler (1899-1901) \\
\hline $\begin{array}{l}\text { Cape May and } 60 \mathrm{~km} \text { off } \\
\text { Winterquarter, N. J. }\end{array}$ & October, 1931 & Bigelow and Sears (1939) \\
\hline Delaware Bay region & July-November, 1929-32 & Deevey (1960) \\
\hline Block Island Sound & August-November, 1943-45, 1949 & Deevey (1952a, 1952b) \\
\hline Woods Hole, Mass. & $1944-53$ to present & Lochhead (1954), N. Marcus ${ }^{a}$ \\
\hline Lower Chesapeake Bay & August-September, 1971-73 & Bryan and Grant (1979) \\
\hline New York Bight $(<50 \mathrm{~m})$ & August-November, 1974-75 & Judkins et al. (1980) \\
\hline
\end{tabular}

a Personal communication. 
Sound which is about $90 \mathrm{~km}$ WSW of Woods Hole (Deevey, 1952a, 1952b). In the Northeast Atlantic, Penilia has been found at two isolated stations in the North Sea, $52^{\circ} 22^{\prime} \mathrm{N}$ and $52^{\circ} 09^{\prime} \mathrm{N}$ (Cattley and Hardy, 1949). In view of the restricted distribution of Penilia in both time and space, the extent and nature of its distribution, as revealed by recent plankton surveys of continental shelf waters between Cape Hatteras and Nova Scotia, are somewhat surprising. In this paper, data on the distribution and abundance of Penilia during bimonthly plankton surveys in 1980 and 1981 are presented, and an attempt is made to explain the observed distributional patterns in respect to hydrographic conditions.

\section{Data Sources}

Zooplankton samples were collected during plankton surveys (Table 2) of continental shelf waters between Cape Hatteras and Nova Scotia as part of the Marine Resources Monitoring, Assessment, and Prediction (MARMAP) Program of the U.S. National Marine Fisheries Service (Sherman, 1980). The area of coverage (shaded) during these surveys and the names of places referred to in the text are shown in Fig. 1. The sampling gear $(61-\mathrm{cm}$ bongo nets) and methodology (double oblique tows at 1.5-2.0 knots to a maximum depth of $200 \mathrm{~m}$ ) were described by Smith and Richardson (1977) and Posgay and Marak (1980). Zooplankton taxa were identified and enumerated at the Morski Instytut Rybacki, Szczecin, Poland. Abundance estimates are based on samples from the $0.333-\mathrm{mm}$ mesh nets that were deployed during the surveys.

\section{Distribution of Penilia and Surface Temperature}

In addition to the distribution of Penilia during the summer and autumn surveys, surface temperature distributions are also shown in Fig. 2 and 3 , because it has been proposed that the distribution of Penilia is limited only by the need of a certain minimum surface water temperature in summer (Fuller, 1950; Lochhead, 1954). In 1980, Penilia first appeared in the samples during the July-August period (Fig. 2A), and the most extensive concentration occurred south of $40^{\circ} \mathrm{N}$ (Barnegat Inlet, New Jersey, to Cape Hatteras, North Carolina) and

TABLE 2. Research vessels and dates of plankton surveys in 1980 and 1981

\begin{tabular}{|c|c|c|c|}
\hline \multicolumn{2}{|c|}{1980} & \multicolumn{2}{|c|}{1981} \\
\hline Vessel & Dates & Vessel & Dates \\
\hline Albatross IV & $28 \mathrm{Feb}-04 \mathrm{Apr}$ & Albatross IV & $17 \mathrm{Feb}-24 \mathrm{Mar}$ \\
\hline Evrika & 14 Apr-15 May & Delaware II & 07 Mar-14 May \\
\hline Delaware II & 21 May-12 Jun & Delaware II & 21 May-17 Jun \\
\hline Evrika & 14 Jul-11 Aug & Delaware II & 27 Jun-19 Jul \\
\hline Albatross IV & 24 Sep-30 Oct & Delaware II & \\
\hline \multirow[t]{3}{*}{ Albatross IV } & 17 Nov-23 Dec & Albatross IV $\}$ & 04 Aug-02 Sep \\
\hline & & Delaware II \} & \\
\hline & & Albatross IV $\}$ & 17 Sep-09 Nov \\
\hline
\end{tabular}

extended offshore to the $100-\mathrm{m}$ contour. The highest numbers of Penilia $\left(>100,000 / \mathrm{m}^{2}\right)$ were taken in a midshelf area (approximately $10,000 \mathrm{~km}^{2}$ ) southeast of Delaware Bay. Isolated patches of Penilia occurred in relatively shallow water $(<50 \mathrm{~m})$ in New York Bight and off central Long Island and Block Island. Penilia were not found east of Block Island $\left(71^{\circ} 35^{\prime} \mathrm{W}\right)$. The distribution of Penilia, for the most part, was restricted to areas where sea-surface temperatures were higher than $18^{\circ} \mathrm{C}$, but Penilia did not occur in areas of the Gulf of Maine or along the southern edge of Georges Bank where surface temperatures were higher than $18^{\circ} \mathrm{C}$.

The distribution of Penilia during SeptemberOctober 1980 (Fig. 2B) was the most extensive of any that was encountered during the surveys. With the exception of a few offshore stations $(>100 \mathrm{~m})$ off southern New England and Long Island, the distribution of Penilia was continuous over the whole of the continental shelf from just west of Nantucket Shoals $\left(70^{\circ} 20^{\prime} \mathrm{W}\right)$ to Cape Hatteras. Penilia were not found in the vicinity of Nantucket Shoals, an area of upwelling as indicated by the $12^{\circ} \mathrm{C}$ surface isotherm, but three extensive, isolated concentrations were found over Georges Bank. The most easterly positive tow was made at $66^{\circ} \mathrm{W}$. West of Nantucket Shoals, Penilia occurred only where surface temperatures were higher than $16^{\circ} \mathrm{C}$. On Georges Bank, Penilia were found in areas where surface temperatures were slightly lower $\left(14^{\circ}\right.$ to $\left.15^{\circ} \mathrm{C}\right)$.

By November-December 1980 (Fig. 2C), both the abundance and the area of occurrence of Penilia had decreased appreciably. The highest numbers were in the range of $1,000-10,000 / \mathrm{m}^{2}$, and the main concentration of Penilia was in the southern part of the Middle Atlantic Bight, extending from just south of Sandy Hook to just south of the entrance to Chesapeake Bay. The central part of this concentration extended offshore to the 1,000-m contour, but Penilia were restricted to midshelf and shallower wates at the northern and southern extremes. An isolated concentration (approximately $3,000 \mathrm{~km}^{2}$ ) occurred within midshelf waters eastward from the eastern end of Long Island. Penilia was not found east of $69^{\circ} \mathrm{W}$ and occurred for the most part at 'ocations where surface temperatures ranged from $8^{\circ}$ to $12^{\circ} \mathrm{C}$.

Penilia did not occur in the samples again until June-July 1981 (Fig. 3A) and then only at isolated locations west of $72^{\circ} \mathrm{W}$ in the Middle Atlantic Bight and, unexpectedly, at a single station on the northeast part of Georges Bank. All positive tows in the Middle Atlantic Bight were made in areas where surface temperatures exceeded $20^{\circ} \mathrm{C}$, whereas the surface temperature at the single positive station on Georges Bank was $16^{\circ} \mathrm{C}$

The area of occurrence and abundance of Penilia had increased markedly by August-September 1981 


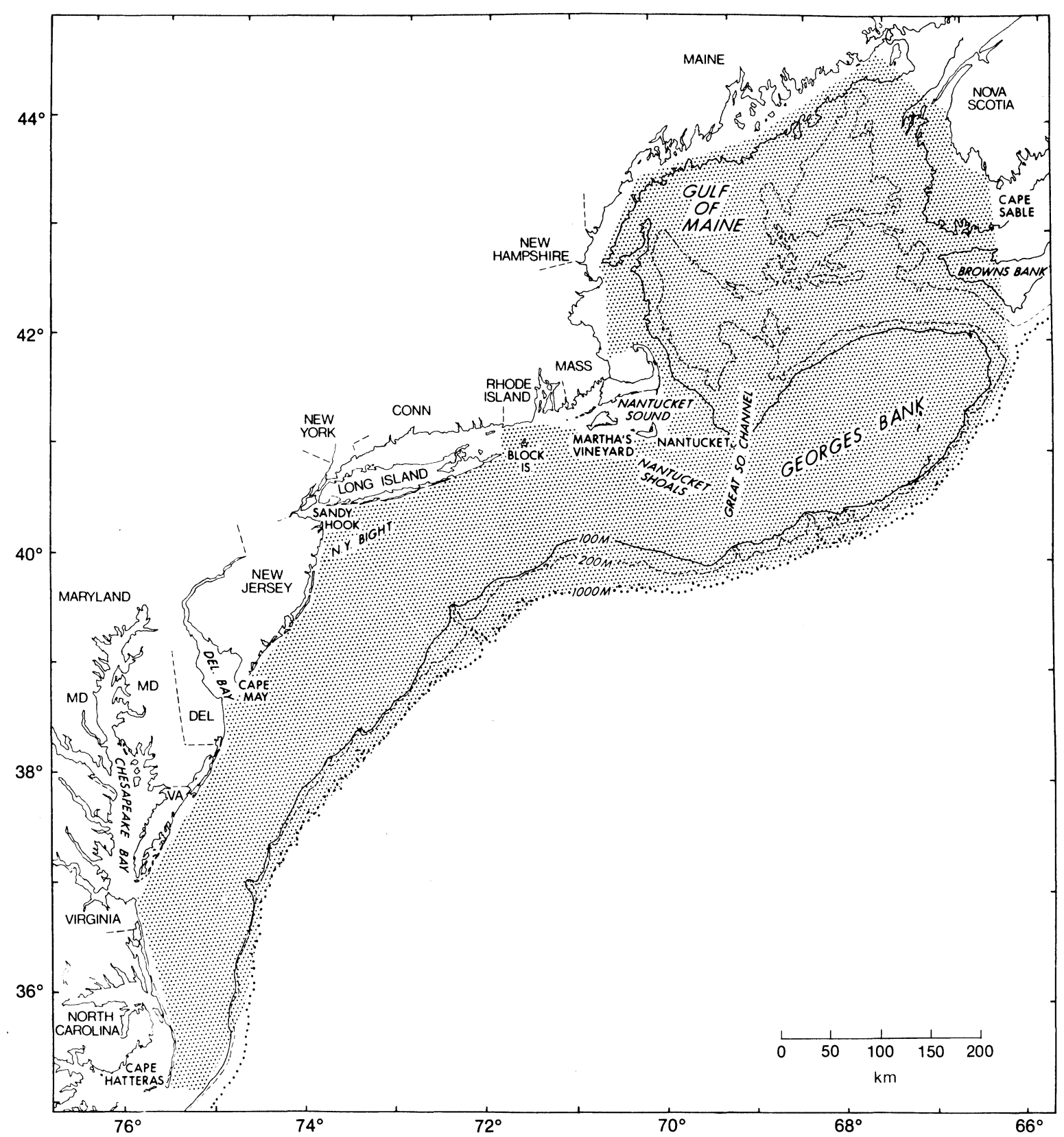

Fig. 1. Orientation map of the survey area (shaded) and place names mentioned in the text.

(Fig. 3B). The inshore distribution of Penilia was restricted to a narrow stretch of the New Jersey-Delaware coastline between $40^{\circ} \mathrm{N}$ and $38^{\circ} \mathrm{N}$, whereas the offshore distribution extended from the eastern tip of Long Island to the southern extreme of the sampling area. Maximum abundance $\left(>100,000 / \mathrm{m}^{2}\right)$ of Penilia occurred at nine stations running across the shelf from just south of the entrance to Delaware to the $100-\mathrm{m}$ contour. The most easterly catches of Penilia were made at two isolated stations just south of Block Island. All positive tows were made in areas where surface temperatures were above $21^{\circ} \mathrm{C}$.
Except for an isolated station on Nantucket Shoals, the distribution of Penilia during SeptemberNovember 1981 (Fig. 3C) was restricted to areas west of Martha's Vineyard $\left(69^{\circ} \mathrm{W}\right)$. Although Penilia was found throughout the Middle Atlantic Bight, its distribution was extremely patchy, which is perhaps a precursor to its impending seasonal demise from the plankton community. Concentrations of Penilia tended to be more extensive and spread further offshore in the southern than in the northern part of the Middle Atlantic Bight. With the exception of the isolated station on Nantucket Shoals where the surface 
1980

A. 14 Jul-11 Aug B. 24 Sep-30 Oct $\quad$ C. 17 Nov-23 Dec

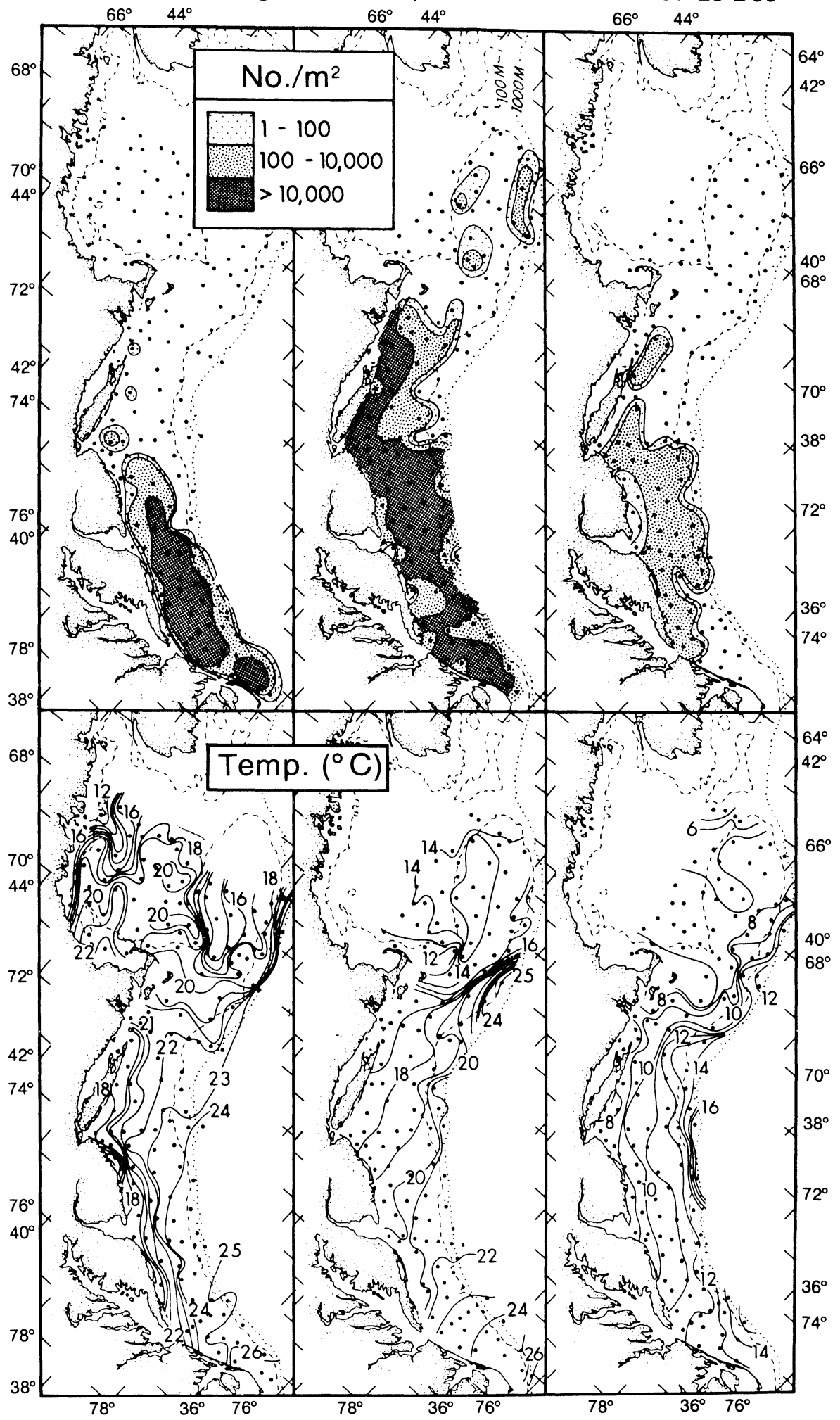

Fig. 2. Distribution and abundance of $P$. avirostris and surface temperatures, July-December 1980. 
1981
A. 27 Jun-19 Jul
B. 4 Aug-2 Sep
C. $17 \mathrm{Sep}-9 \mathrm{Nov}$

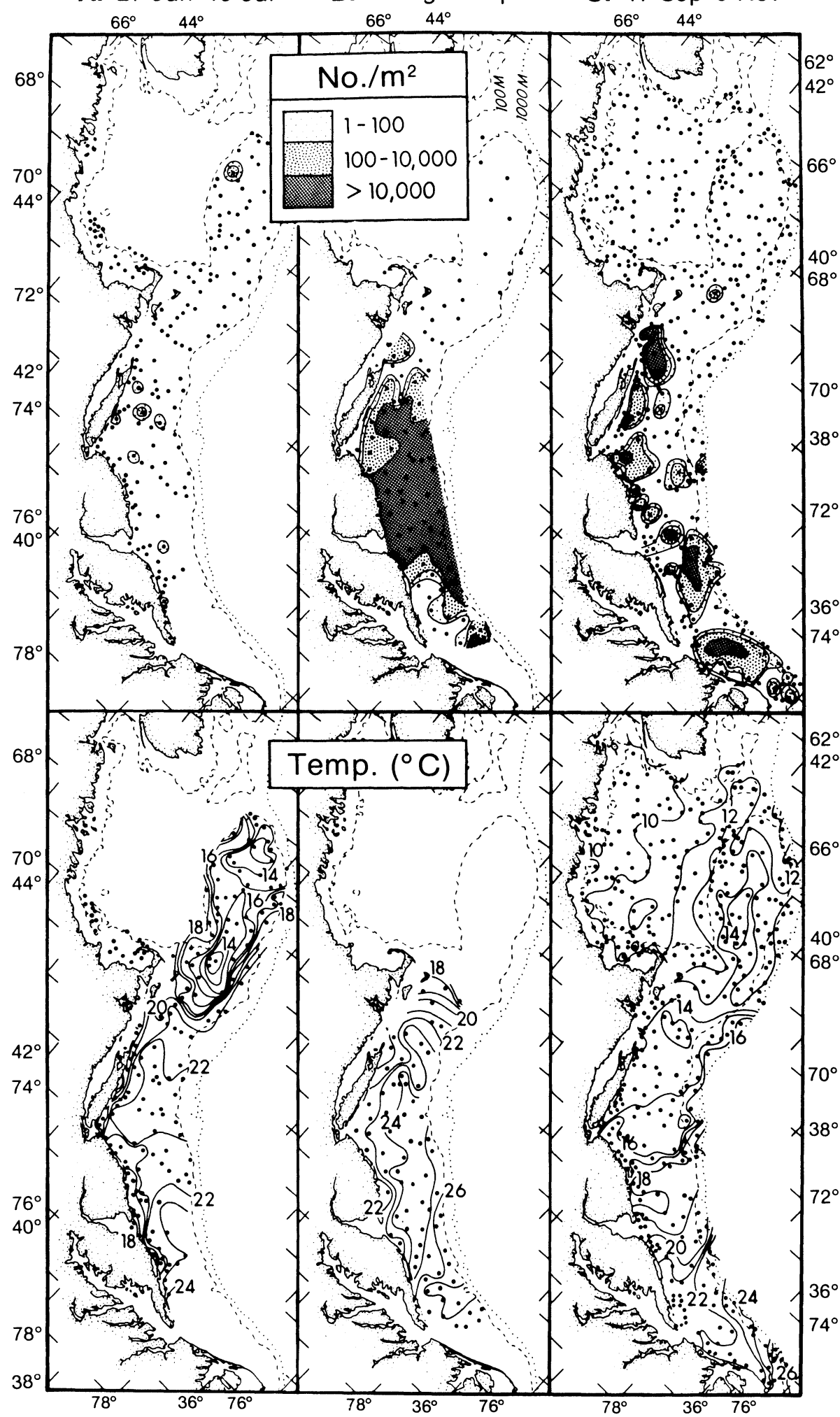

Fig. 3. Distribution and abundance of $P$. avirostris and surface temperatures, June-November 1981. 
temperature was $12^{\circ} \mathrm{C}$, the distribution of Penilia was restricted to areas where the surface temperatures were higher than $14^{\circ} \mathrm{C}$.

\section{Discussion}

Apparently, sampling in the Gulf of Maine has been adequate enough in the past (e.g. Bigelow, 1926; Fish and Johnson, 1937) and during recent years (Sherman, 1980) to state unequivocally that Penilia does not occur in the Gulf of Maine. Evadne sp. and Podon sp. have been reported from scattered inshore stations throughout the Gulf of Maine (Bigelow, 1926; Fish and Johnson, 1937) and from as far north as the Grand Bank off Newfoundland (Gieskes, 1971, Semenova, 1964; Vladimirskaya, 1965). Up to the present time, survey coverage of the Georges Bank area has been infrequent and biased towards the spring months of the year, so that it cannot be said with any degree of certainty that Penilia did or did not occur on Georges Bank prior to 1980. This eastward extension of the distribution of Penilia corresponds to the direction of range expansion previously documented (Table 2) but is at variance with the direction of residual drift throughout the Middle Atlantic Bight, which is to the west and southwest (Bumpus, 1973; Butman et al., 1982; Colton and Anderson, 1983). Therefore, the eastward dispersion of Penilia by surface drift must be ruled out as a causal factor.

Lochhead (1954) suggested that the sudden appearance of Penilia in new areas is perhaps a result of recently-laid resting eggs becoming caught up in wind-driven spray. However, this does not seem likely in the present case, because the distance from its former eastern distributional limit (Woods Hole) to Georges Bank is some $200 \mathrm{~km}$ or more. Lochhead (1954) ruled out the possibility of the transport of resting eggs after becoming attached to the feet (or feathers) of birds, as is often the case in freshwater Cladocera (and fish eggs and larvae). This may not be as remote a possibility as it first appears, because it is likely that some of the herring gulls (Larus argentatus) that breed and nest along the shores of Nantucket and Vineyard Sounds during late spring commute to Georges Barik in the summer (W. H. Drury, College of the Atlantic, Bar Harbor, Maine, pers. comm., 1985). Another likelihood is that Penilia are carried to Georges Bank in the salt-water cooling systems of many fishing vessels which travel to Georges Bank from southern New England ports via Nantucket Sound.

Regardless of how Penilia arrived on Georges Bank, a main point of interest is to determine why the distribution is completely isolated and restricted to Georges Bank itself and does not extend northward into the Gulf of Maine or westward across the Great
South Channel and Nantucket Shoals to connect with the apparent progenitor population. Because adult Penilia apparently always occur close to the surface (upper $20 \mathrm{~m}$ of the water column), investigators have resorted to surface temperature conditions (minimum temperature necessary for reproduction in summer) to account for the observed distributional patterns. Lochhead (1954), on the basis of observations at Woods Hole and a thorough review of the literature, concluded that adults can survive at temperatures below $9^{\circ} \mathrm{C}$ and can reproduce when temperatures are at and perhaps below $16^{\circ} \mathrm{C}$, but that they do not become permanently established except where summer water temperatures exceed $21^{\circ} \mathrm{C}$.

Maximum sea-surface temperatures of Slope Water along the edge of the shelf (seaward of 200-m isobath) alway exceed $21^{\circ} \mathrm{C}$ (Colton and Stoddard, 1972), but Penilia does not occur in these waters (at least east of $70^{\circ} \mathrm{W}$ longitude). This implies that a factor or factors other than sea-surface temperature control the observed distributional patterns. Gieskes (1971) has suggested that, because Cladocera are daylightfeeding surface-water animals, they are restricted to shallow-water areas or to well-stratified deeper waters where vertical turbulence is limited and transport of animals to unfavorable environments cannot take place. This hypothesis could account for the confinement of Penilia to the shallow, although well-mixed, waters of Georges Bank. Another possibile determinant is the necessity of a minimum bottom-water temperature to initiate the development of the resting eggs. Average long-term bottom-water temperatures in August, September and October and annual maximum bottom-water temperatures (Fig. 4) support this premise in that bottom-water temperatures at depths greater than $100 \mathrm{~m}$ in the warmest months were less than $10^{\circ} \mathrm{C}$ throughout the Gulf of Maine and $10^{\circ} \mathrm{C}$ or less along the shelf break $(>200 \mathrm{~m})$. Bottom-water temperatures over Georges Bank were as high as, and in some cases higher than, those in the Middle Atlantic Bight. A marked discontinuity in bottom-water temperatures occurred in the deeper parts of the Great South Channel. If sufficient numbers of viable resting eggs of Penilia could be obtained, verification of the hypothesis relating bottom-water temperature to survival would appear to be most amenable to laboratory study.

Regardless of whether the distribution of Penilia is limited by a minimum sea-surface temperature (necessary for sexual reproduction) or a minimum bottomwater temperature (necessary to initiate the development of resting eggs), long-term temperature observations (Colton and Stoddard, 1972, 1973) indicate that Georges Bank may constitute the eastern extreme of its range in the Northwest Atlantic. If seasurface temperature is the primary controlling variable, the occurrence of Penilia on Georges Bank would be expected to be sporadic, because surface water of 


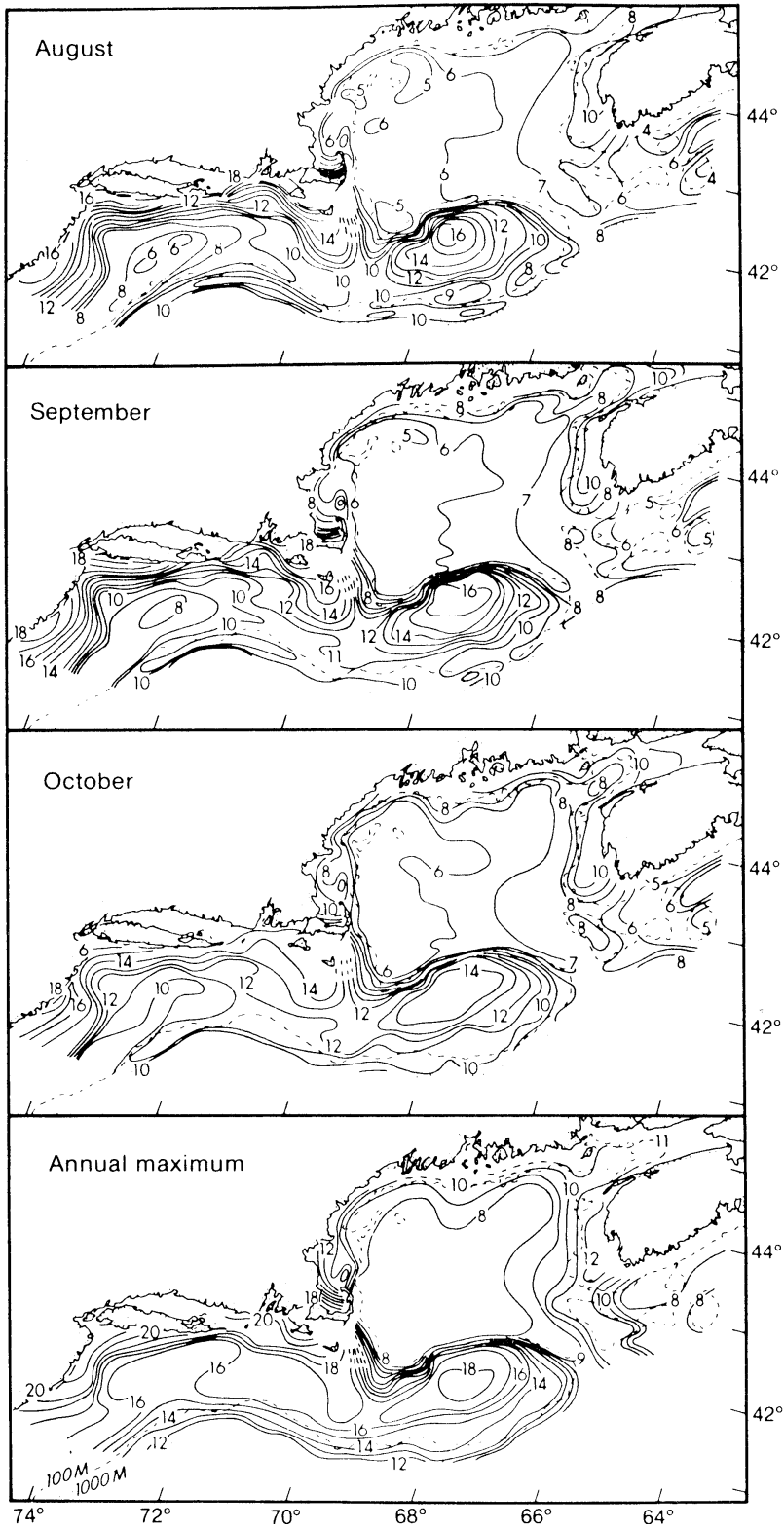

Fig. 4. Distribution of long-term average bottom water temperatures during August, September and October, and long-term annual maximum bottom temperatures (Colton and Stoddard, 1973).

$21^{\circ} \mathrm{C}$ or higher is only found over Georges Bank irregularly. If, however, bottom-water temperature $\left(>10^{\circ} \mathrm{C}\right)$ is the primary determinant, Penilia would be expected to become permanently established on Georges Bank.

\section{References}

BIGELOW, H. B. 1926. Plankton of the offshore waters of the Gulf of Maine. Bull. U.S. Bur. Fish., 40: 1-509.

BIGELOW, H. B., and M. SEARS. 1939. Studies of the waters on the continental shelf, Cape Cod to Chesapeake Bay. III. A volumentric study of the zooplankton. Mem. Mus.
Comp. Zool. Harv. Univ., 54: 179-378.

BRYAN, B. B., and G. C. GRANT. 1979. Parthenogenesis and the distribution of the Cladocera. Bull. Biol. Soc. Wash., 3: 54-59.

BUMPUS, D. F. 1973. A description of the circulation of the continental shelf of the east coast of the United States. Prog. Oceanogr., 6: 111-157.

BUTMAN, B., R. G. BEARDSLEY, B. MAGNELL, J. A. VERMERSCH, R. J. SCHLITZ, R. LIMEBURNER, and M. A. NOBLE. 1982. The mean circulation on Georges Bank. J. Phys. Oceanogr., 12: 569-591.

CATTLEY, J. G., and J. P. HARDING. 1949. Penilia, a cladoceran normally found off tropical and subtropical coasts, recorded in North Sea plankton. Nature, Lond., 164: 238239.

COLTON, J. B. Jr., and J. L. ANDERSON. 1983. Residual drift and residence time of Georges Bank surface waters with references to the distribution, transport, and survival of larval fishes. NOAA Tech. Memo., NMFS-F/NEC-24: $44 \mathrm{p}$.

COLTON, J. B., Jr., and R. R. STODDARD. 1972. Average monthly sea water temperatures, Nova Scotia to Long Island, 1940-59. Amer. Geographic Soc. Serial Atlas of the Marine Environment, Folio 21, 19 p. +10 pl.

1973. Bottom-water temperatures on the continental shelf, Nova Scotia to New Jersey. NOAA Tech. Rep. NMFS Circ., 376: 1-55.

DEEVEY, G. B. 1952a. A survey of the zooplankton of Block Island Sound, 1943-1946. Bull. Bingham Oceanogr. Coll., 13: $65-119$.

1952b. Quantity and composition of the zooplankton of Block Island Sound, 1949. Bull. Bingham Oceanogr. Coll., 13: 120-164.

1960. The zooplankton of the surface waters of the Delaware Bay region. Bull. Bingham Oceanogr. Coll., 17: 5-53.

FISH, C. J., and M. W. JOHNSON. 1937. The biology of the plankton populations in the Bay of Fundy and Gulf of Maine with special reference to production and distribution. J. Biol. Board Can., 3: 189-322.

FULLER, A. S. 1950. Temperature requirements of Penilia avirostris Dana in the Hauraki Gulf, New Zealand. Nature, Lond., 165, p. 734.

GIESKES, W. W. C. 1971. Ecology of the Cladocera of the North Atlantic and the North Sea, 1960-1967. Neth. J. Sea Res., 5: 342-376.

JUDKINS, D. C., C. D. WIRICK, and W. E. ESAIAS. 1980. Composition, abundance, and distribution of zooplankton in the New York Bight, September 1974-September 1975. Fish. Bull. U.S., 77: 669-683.

LOCHHEAD, J. H. 1954. On the distribution of a marine cladoceran Penilia avirostris Dana (Crustacea, Branchiopoda) with a note on its reported bioluminescence. Biol. Bull. Mar. Biol. Lab., Woods Hole, Mass., 107: 92-105.

POSGAY, J. A., and R. R. MARAK. 1980. The MARMAP bongo zooplankton samplers. J. Northw. Atl. Fish. Sci., 1: 91-99.

SEMENOVA, T. N. 1964. The seasonal phenomena in the plankton of the Labrador shelf, the Grand Banks of Newfoundland, and Flemish Cap Bank. Tr. PINRO, Murmansk, 16: 49-77.

SHERMAN, K. 1980. MARMAP, a fisheries ecosystem study in the Northwest Atlantic: fluctuations in ichthyoplanktonzooplankton components and their potential impact on the system. In Advanced concepts in ocean measurements for the marine biology (p.9-37), F. P. Diemer, F. J. 
Vernberg, and D. Z. Mirkes (ed.), Univ. S. Carolina Press, Columbia, S.C., 572 p.

SMITH, P. E., and S. L. RICHARDSON. 1977. Standard techniques for pelagic fish egg and larvae surveys. FAO Fish. Tech. Pap., 175: 100 p.
SUDLER, M. T. 1899-1901. The development of Penilia schmarkeri Richard. Proc. Boston Soc. Nat. Hist., 29: 109-132.

VLADIMIRSKAYA, E. V. 1965. Distribution of plankton in the Newfoundland area. Tr. VNIRO, Moscow, 57: 361-380. 